\title{
II Encontro de Editores de Revistas Cientfficas
}

Realizado no Instituto de Ciências Biomédicas, USP, em Sẵo Paulo, SP, aos 27 e 28 de novembro de 1985. A Plenária do Encontro aprovou recomendação às revistas cientfficas alf representadas para que fosse publicado o "Documento Final do Encontro", cuja integra é a seguinte:

\section{A. PREMISSAS}

1. A polftica de divulgaçăo cientffica e tecnológica é parte integrante da poIf́tica global de ciência e tecnologia do país $\theta$, por conseqüência, o financiamento desta atividade deverá constar dos orçamentos e dos programas de Pesquisa e Desenvolvimento das agências financiadoras e de outras instituiçőes.

Para adequar os recursos às reais necessidades do setor, seriam necessários, no mínimo, $2 \%$ dos recursos efetivamente alocados à Pesquisa e Desenvolvimento pelas agências financiadoras e pelas instituiçס̋es de pesquisa.

2. O pesquisador brasileiro deve ser conscientizado de sua responsabilidade na publicaçăo ampla dos resultados de seu trabalho em revistas cientfficas nacionais. 
3. Os progressos da pesquisa cientffica e tecnológica do pals, estăo a exigir um salto qualitativo e quantitativo na informaçăo cientiffica e tecnológica.

4. Deve ser reconhecida a importância das revistas cientificas como espeIho da produção cientffica nacional.

\section{B. RECOMENDAÇÕES ÀS AGÊNCIAS FINANCIADORAS E ÓRGÃOS PÚBLICOS}

1. que as agências financiadoras estudem mecanismos de pagamento de salários às equipes de editoraçăo cientifica, visando criar estruturas profissionais;

2. que o MEC destine recursos às bibliotecas universitárias para assinatura de revistas cientificas nacionais de boa qualidade;

3. que as agências coordenadoras do Programa Setorial de Publicaçóes em Ciência e Tecnologia concedam - por tempo determinado - um adicional de $15 \%$ sobre o total de recursos fornecidos a cada revista, para que a entidade responsável pela publicação envie 200 exemplares a bibliotecas, entidades e grupos de sua área de especializaçăo localizadas no Brasil e 100 exemplares para bibliotecas congêneres no exterior. Tais recursos adicionais destinam-se a cobrir os custos com manipulação, embalagem e postagem dos exemplares. Os editores proporão as entidades a serem contempladas, para referendo pela agência financiadora.

4. que haja maior pontualidade na liberação dos recursos pelos órgãos financiadores. A notificação da aprovação e valor do financiamento deve ser imediata, para fins de planejamento.

5. que a avaliação de revistas cientificas da mesma área por parte das agências financiadoras seja feita em conjunto para melhor julgamento;

6. que as agências financiadoras criem mecanismos de estimulo à publicação, em revistas cientificas nacionais, dos resultadus dos projetos de pesquisa por elas financiados. Tal estfmulo deve ser estendido à publicaçāo de resumos e/ou artigos baseados em teses de pós-graduação.

7. que a FINEP estimule as pequenas e médias empresas nacionais, por ela financiadas, a veicular anúncios de seus produtos nas revistas científicas nacionais;

8. que haja maior articulação entre as agências financiadoras. 